\title{
Communication
}

[Comunicação]

\section{Detection of several clostridia by a direct fluorescent antibody test in formalin-fixed, paraffin-embedded tissues}

\author{
[Detecção de clostrídios pela técnica de imunofluorescência direta em tecidos fixados em formol \\ e incluidos em parafina] \\ R.A. Assis $^{1}$, F.C.F. Lobato $^{2 *}$, F.M. Salvarani ${ }^{2}$, C.G.R.D. Lima $^{2}$, F.A. $U z a l^{3}$ \\ ${ }^{1}$ Ministério da Agricultura, Pecuária e Abastecimento - Pedro Leopoldo, MG \\ ${ }^{2}$ Escola de Veterinária - UFMG \\ Caixa Postal 567 \\ 30123-970 - Belo Horizonte, MG \\ ${ }^{3}$ California Animal Health and Food Safety Laboratory - San Bernardino-CA, USA
}

\begin{abstract}
Blackleg and malignant oedema are infectious conditions of cattle, sheep, goats, and other animals produced by microorganisms of the Clostridium genus. Blackleg is mainly a myonecrosis produced by Clostridium chauvoei, while malignant oedema affects muscular and subcutaneous tissues, and can be caused by Clostridium chauvoei, Clostridium septicum, Clostridium sordellii, Clostridium novyi type A, and Clostridium perfringens type A acting alone or in combination. Both conditions are of significant economic importance for the cattle industry worldwide. For instance, in Minas Gerais, Brazil, 14,895 cases of blackleg and malignant oedema were recorded from 1990 to 2004 (Olinda, S., personal communication ${ }^{1}$.
\end{abstract}

While a presumptive diagnosis of blackleg or malignant oedema can be established based on clinical signs and gross post-mortem findings, a definitive diagnosis of these conditions should be based upon identification of the bacteria involved. Conventionally, this is achieved by culturing and isolating these microorganisms or by their demonstration using labelled antibodies. Amongst the latter, fluorescent antibodies are traditionally used on smears of tissues or cultures (Pinto and Abreu, 1992).

Recebido em 2 de fevereiro de 2007

Aceito em 5 de outubro de 2007

*Corresponding author (autor para correspondência)

E-mail: flobato@vet.ufmg.br
Immunohistochemical techniques have been used to demonstrate several clostridial organisms in formalin-fixed, paraffin-embedded tissues (Vanelli and Uzal, 1996a; Vanelli and Uzal, 1996b; Assis et al., 2005). These techniques are particularly useful when only formalin-fixed tissues are available for diagnosis. In an attempt to reduce processing times for diagnosis of blackleg and malignant oedema, a fluorescent antibody technique (FAT) to detect C. chauvoei, C. septicum, C. sordellii, and C. novyi type A in formalin-fixed, paraffin-embedded tissues of guinea-pigs was used in this study.

Fluorescent conjugates anti-C. chauvoei, anti- $C$. septicum, anti-C. sordellii, and C. novyi type A were prepared as previously described (Assis et al., 2001). Briefly, antisera were prepared in rabbits vaccinated with inactivated cultures of $C$. chauvoei (strain ATCC 10092), C. septicum (strain ATCC 12464), C. sordellii (ATCC 9714), or C. novyi type A (ATCC 19402), and emulsified in incomplete Freund's adjuvant ${ }^{2}$. The immunoglobulins of the rabbit sera were precipitated using a saturated ammonium sulphate solution and dialysed against phosphate buffered saline, $\mathrm{pH} 7.2$ (PBS). The IgG fraction was separated by ion-exchange chromatography using a diethylaminoethyl (DEAE) cellulose column and the immunoglobulins were

\footnotetext{
${ }^{1}$ Solange Olinda, 2007 - Mapa - Belo Horizonte.

${ }^{2}$ Sigma - St. Louis, U.S.A
} 
conjugated with fluorescein isotiocyanate- FITC ${ }^{3}$ as described by Wood et al. (1965). The conjugates were diluted to 1:2 with glycerol and stored at $-20^{\circ} \mathrm{C}$. From the same rabbits, serum obtained prior to immunization was used as normal rabbit serum in control slides.

The conjugates were evaluated for sensitivity and specificity using a FAT (Pinto and Abreu, 1992) on smears of C. chauvoei (strain ATCC 10092), C. septicum (strain ATCC 12464), C. sordellii (strain ATCC 9714), and C. novyi type A (strain ATCC 19402). The sensitivity was assessed by preparing two-fold dilutions of each conjugate (from 1:2 to 4096) and incubating with the corresponding smear.

Formalin-fixed, paraffin-embedded tissues from 12 guinea-pigs previously intramuscularly inoculated with either a pure culture of $C$. chauvoei (strain ATCC 10092), C. septicum (strain ATCC 12464), C. sordellii (strain ATCC 9714), or C. novyi type A (strain ATCC 19402) (three animals for each microorganism), were used. All the inocula consisted of $0.25 \mathrm{ml}$ of culture plus $0.25 \mathrm{ml}$ of a sterile $5 \%$ calcium chloride solution. Skeletal muscles, heart, spleen, liver, and kidneys were available and $5 \mu \mathrm{m}$ thick sections were cut and mounted on chrome alum ${ }^{2}$ pre-treated slides to the HE and FAT. This experiment was carried out according to the Ethics Committee ${ }^{4}$ permission.

The sections were deparaffinised with xylene and re-hydrated with graded alcohols to water, before the conjugates were applied. The slides were incubated for 30 minutes in darkness at $37^{\circ} \mathrm{C}$, washed twice with PBS and once with distilled water. Then, the sections were counterstained by immersion in a $0.2 \%$ Evan's blue solution for 20 seconds, rinsed in PBS and mounted with buffered glycerol $\mathrm{pH}$ 8.0. A fluorescence microscope was used for observation.

Sections of skeletal muscle containing $C$. chauvoei, C. septicum, C. sordellii, and C. novyi type A, in which Gram positive bacilli had been observed by Maccallum-Goodpasture (Luna, 1968) were used as positive control.

${ }^{3}$ Merck - Darmstadt, Germany

${ }^{4}$ CETEA - UFMG (104/04).
The ideal dilutions for the $C$. chauvoei, $C$. septicum, C. sordellii, and C. novyi FITC conjugates were 1:256, 1:512, 1:1024 and 1:1024, respectively. No cross-reactions were observed between any of the conjugates, nor in any of the tests. The sections treated with normal rabbit serum were negative and the sections of skeletal muscle treated with the conjugates corresponding for each one of these microorganisms were positive. C. chauvoei and C. septicum were detected by FAT in all the tissues using the corresponding conjugates, while C. sordellii and $C$. novyi were detected only in the skeletal muscle sections of all clostridia. Histological examination showed muscular lesions similar in all clostridia inoculated and were characterized by a neutrophilic inflammatory response associated with degenerative changes including hypercontraction and hyalinisation of muscle fibers and loss of striations. These changes were associated with variable degrees of interstitial oedema and haemorrhage. Basophilic rods were consistently observed only in the muscle tissue of animals infected with all tested clostridia, with frequency ranging from 60 to $90 \%$. These rods were located in the interstitium. Mild hyperemia and focal haemorrhage were observed in sections of liver, spleen, kidney, and myocardium in all animals with inoculated clostridia. Clusters of basophilic rods were observed in sections of the liver, spleen, heart, and kidneys from animals infected with $C$. septicum.

In skeletal muscle the FAT revealed the presence of numerous rods, singly or in clusters among the muscular fibres from all sections of all clostridia. In all sections of $C$. chauvoei and $C$. septicum in the FAT positively stained rods were observed. In the liver they were observed in the periportal and periacinar areas; in the spleen, mainly in the interstitium; in the myocardium, inside of lumen of vessels; and in the kidney they were observed in the interstitium and blood vessels of the cortex and medulla.

The FAT is routinely used to diagnose blackleg and malignant oedema on tissue or culture smears. The use of this technique is described here to diagnose these two diseases on formalinfixed, paraffin-embedded tissues.

The references concerning the use of the FAT technique in formalin-fixed, paraffin-embedded 
tissues in the literature are scant. A FAT was used by Glastonbury et al. (1988) and Uzal et al. (2003) on formalin-fixed, paraffin-embedded tissues in cases of clostridial myocarditis caused by $C$. chauvoei in lambs and calves, respectively, and by Ortega et al. (2007) in cases of navel infection of foals caused by $C$. sordellii. To the best of our knowledge, those seem to be the only published reports of the use of a FAT for detection of clostridia in formalin-fixed, paraffin-embedded tissues. In the above mentioned studies, the technique was applied only to the myocardium and the navel, however in this study, the FAT showed to be also efficient to detect $C$. chauvoei and $C$. septicum in sections from other organs. Nevertheless, this study was performed on guinea pigs and it is unknown if the same principle applies to sheep, cattle or other animal species. A variation from the procedure used by Glastonbury et al. (1988) was the no-refixing in anhydrous acetone and they were counterstained by immersion in a $0.2 \%$ Evan's blue solution. This counterstain was also used by Uzal et al. (2003) and Ortega et al. (2007) in a FAT for C. chauvoei and C. sordellii on formalin-fixed, paraffin-embedded tissues of cattle and equine, respectively. The Evan's blue counterstain provides a much better observation of tissue morphology and also provides a stronger contrast for the fluorescent microorganisms.

In this study, the tissues sections were fixed in formalin by 24 hours to avoid antigenic masking due to protein link (Gimeno, 1995).

The FAT allowed a quick and specific identification of $C$. chauvoei, C. septicum, $C$. sordellii, and $C$. novyi type $\mathrm{A}$ in tissues of skeletal muscle of guinea pigs processed for routine histology, thus providing a simple and rapid method to diagnose blackleg and malignant oedema. This technique will be particularly useful in areas where laboratory facilities for anaerobic cultivation are not readily available and in any situation in which fixed rather than fresh tissues are submitted to the laboratory. In a recent work, carried out by Assis et al. (2005) comparing the techniques of FAT and immunohistochemistry using the streptavidinbiotin technique to detect several clostridia, showed that both techniques present the same sensibility and specificity. However, the FAT has important advantages in comparison with different immunohistochemical techniques. Firstly, the FAT is faster, usually taking approximately one hour as opposed to the seven or more hours required to complete the steps required using the immunohistochemical techniques. Secondly, the FAT is less expensive. It does not require the acquisition of the costly kits for diagnosis which are necessary for other techniques, and laboratories can efficiently produce their proper conjugates to use in the FAT at a low cost. The FAT standardised in this study for detection of $C$. chauvoei, C. septicum, C. sordellii, and $C$. novyi type A, also allows retrospective studies in formalin-fixed, paraffinembedded tissues.

Finally, FAT may significantly improve the success rate for the diagnosis of blackleg and malignant oedema, as well as help establish the prevalence of these diseases in countries, such as Brazil, where laboratory facilities are not always readily available.

Keywords: myonecrosis, clostridia, fluorescent antibody test.

\section{RESUMO}

Descreve-se a aplicabilidade de uma técnica de imunofluorescência direta, para o diagnóstico de mionecroses causadas por clostrídios, a partir de tecidos fixados em formol e incluidos em parafina. Essa técnica pode auxiliar no diagnóstico do carbúnculo sintomático e da gangrena gasosa, contribuindo para determinar a real prevalência dessas doenças no país.

Palavras-chave: mionecrose, clostrídios, imunofluorescência direta.

\section{AKNOWLEDGEMENTS}

This work was supported by Pro-Reitoria de Pesquisa - UFMG, Conselho Nacional de Desenvolvimento Cientifico e Tecnológico Pesquisa and Fondo Nacional para la Ciencia y la
Tecnología (PICT-01-3591), Argentina. Our thanks to LANAGRO - MAPA, Pedro Leopoldo, MG - for providing the experimental animals, to E. N. Vidál, Marilene de Almeida Campos and Mardelene Geisa Gomes, for their technical assistance. 


\section{REFERENCES}

ASSIS, R.A.; LOBATO, F.C.F.; DIAS, L.D. et al. Producción y evaluación de conjugados fluorescentes para diagnóstico de mancha y gangrena gaseosa. Rev. Med. Vet., v.82, p.68-70, 2001.

ASSIS, RA.; LOBATO, F.C.F.; SERAKIDES, $\mathrm{R}$. et al. Immunohistochemical detection of clostridia species in paraffin-embedded tissues of experimentally inoculated guinea pigs. Pesq. Vet. Bras., v.25, p.4-8, 2005.

GIMENO, E.L. Fundamentos da inmunohistoquímica aplicada à patologia veterinária. In: $7^{\circ}$ ENCONTRO NACIONAL DE PATOLOGIA VETERINÁRIA, 7., 1995, Belo Horizonte. Anais...Belo Horizonte: FEPMVZ, 1995. p.17-51.

GLASTONBURY, J.R.W.; SEARSON, J.E.; LINKS, I.J. et al. Clostridial myocarditis in lambs. Aust. Vet. J., v.65, p.208-209, 1988.

LUNA, L.G. (Ed). Manual of the Histologic Staining Methods of the Armed Forces Institute of Pathology. 3.ed. New Work: McGraw Hill, 1968.

ORTEGA, J.; DAFT, B. ASSIS, R.A. et al. Infection of internal umbilical remnant in foals by Clostridium sordellii. Vet. Pathol., v.44, p.269-275, 2007.

PINTO, M.P.; ABREU, V.L.V. Comparação de técnicas para preparo de conjugados antiClostridium septicum e anti-Clostridium chauvoei. Arq. Bras. Med. Vet. Zootec., v.44, p.513-520, 1992.

UZAL, F.A.; PARAMIDANI, M.; ASSIS, R. et al. Outbreak of clostridial myocarditis in calves. Vet. Rec.,v.152, p.134-136, 2003.

VANELLI, S.A.; UZAL, F.A. Identification of Clostridium sordeliii by a peroxidaseantiperoxidase (PAP) technique in formalinfixed, paraffin-embedded tissues of sheep. Rev. Med. Vet., v.77, p.306-312, 1996a.

VANELLI, S.A.; UZAL, F.A. Clostridium septicum detection by the peroxidaseantiperoxidase (PAP) technique in formalinfixed, paraffin-embedded tissues of sheep. Arch. Med. Vet., v.28, p.125-127, 1996b.

WOOD, B.T.; THOMPSON, S.H.; GOLDSTEIN, G. Fluorescent antibody staining. III. Preparation of fluorescein-isothiocyanatelabelled antibodies. J. Immunol., v.95, p.225229, 1965. 